\title{
The Graptophyllum pictum extract effect on acrylic resin complete denture plaque growth
}

\author{
Endang Wahyuningtyas \\ Department of Prosthodontics \\ Faculty of Dentistry Gadjah Mada University \\ Yogyakarta - Indonesia
}

\begin{abstract}
Graptophyllum pictum, in Indonesian is named 'daun ungu', is one of the traditional plants usually used as haemorrhoids medicament in Indonesia; it is composed from alkaloid, pectin, saponin, tannin, flavonoid and alcohol. Graptophyllum pictum is able to prevent the growth of Streptococcus mutans. The purpose of this investigation is to study the effect of Graptophyllum pictum extract toward the growth of plaque on acrylic resin complete denture. For this plaque growth research, 40 samples of acrylic resin complete denture were used, which divided into four groups. Those samples were first treated by cleansing each denture from saliva with running water. The existence of plaque on the complete denture was known by means of disclosing agent. The plaque was then scored by using modified Quigley Hein index, in this case until the plaque was scored zero. The second treatment was soaking the Group I to IV denture samples in Graptophyllum pictum extract with various concentration 5\%, 10\%, 20\% and 40\%, each for 15 minutes. Following this, the dentures were worn by the patients again for four hours, and then removed and washed with water. Then the disclosing agent were rubbed on the dentures and subsequently washed with water. The obtained data were analyzed by One-way variant analysis and t-test. The study result showed there were significant differences among the growth of plaque on acrylic resin complete denture which was soaked in different concentration of Graptophyllum pictum extract $(p<0.05)$. Regarding this result it can be concluded that Graptophyllum pictum extract could inhibit the plaque growth on acrylic resin complete denture. And it seems also that the highest plaque growth inhibition on acrylic resin complete denture is caused by the $40 \%$ concentration extract of Graptophyllum pictum.
\end{abstract}

Key words: Graptophyllum pictum extract, plaque, acrylic resin complete denture

Correspondence: Endang Wahyuningtyas, c/o: Bagian Prostodonsia, Fakultas Kedokteran Gigi Universitas Gadjah Mada. Jln. Denta No. II Sekip Utara, Yogyakarta 55281, Indonesia.

\section{INTRODUCTION}

Metacrilate polymethyl acrylic resin is a common material widely-used in the construction of complete denture bases. Acrylic resin has a good aesthetic property, could match the colour of the substituted mouth tissue naturally, stable form, besides would not cause irritation, non-toxic, and is easy to fabricate and manipulate, as well as to repair if broken. ${ }^{1}$ Most of the acrylic resin's defect are caused by the remaining monomer, water absorbent as well as porosity. ${ }^{2}$

While wearing an acrylic resin complete denture, the mucosa underneath will be covered by the device for a long time, this matter will hinder the cleansing of the denture surface facing the mucosa, by tongue and saliva. ${ }^{3}$ The supporting mucosa tissue of the acrylic resin complete denture, will alter. And this matter related very much to the amount of plaque formation at the fitting surface.

Plaque is a soft non mineralized deposit, originated from bacteria attached to an adhesive matrix which is form-by saliva-glycoprotein and extra cellular bacteria on teeth as well as dentures surfaces. This plaque's matrix is comprised of $80 \%$ water and $20 \%$ solid substances. ${ }^{4}$
The denture's plaque is formed due the long wearing within a certain period of time. The plaque structure on a denture has the same basic composition as those found at an natural teeth. ${ }^{5}$ Denture plaque is the source of periodontal diseases, bad breath odour, changing the denture colour and cause denture stomatitis as well, an infection of the mucosa tissue especially underneath the denture. ${ }^{6}$ Streptococcus mutans is the greatest amount of bacteria found in the dental plaque, because this is their main habitat. They multiply and colonized on the teeth surfaces forming dental plaque. ${ }^{7}$ Because that matter acrylic resin complete denture wearers should attend the hygienic condition by keeping the oral and dentures clean.

The purpose of routine denture cleansing is to avoid plaque growth and prevent their accumulation as well as mucin and calculus deposits. ${ }^{5}$ Generally denture cleansing can be done by mechanical or chemical method. Mechanical cleansing is done by brushing the denture with a soft tooth brush and chemical cleansing is by soaking it into a denture cleansing or disinfectant solution especially for that purpose. 8,9

Graptophyllum pictum, Indonesian named 'daun ungu (violet leave)' is one of the traditional herbal plants 
commonly grow in Indonesia as shrubs. Graptophyllum pictum has pharmacological specialty for various health problems, such as: to release anuria, constipation, haemorrhoids, maturing boil process, weak laxative for purgation, skin softener and to enhance menstrual blood flow. ${ }^{10}$ Graptophyllum pictum consist of chemical content: alkaloid, pectin, and formic acid. It contains also steroid, saponin, tannin, flavonoid and alcohol. ${ }^{11}$

Tannin can be locally applied on wounds at the throat and oral cavity, the later especially in stomatitis. Tannin has a physiological action against bacteria growth. ${ }^{12}$ As a detoxification agent, tannin can precipitate protein and form a specific compound interacting with protein and saliva pellicle ${ }^{13}$ to inhibit the attachment of Streptococcus mutans as well as reducing it. ${ }^{7}$ Alkaloid has a physiological action against bacteria's growth. ${ }^{12,14}$ Flavonoid is a phenol compound, that can dissolve in water, and can be extracted by $70 \%$ ethanol. Flavonoid has an antiviral, antibacterial and anti-inflammation character as well. The general characteristic of phenolic compound is able to increase cell permeability to form a complex compound with protein by hydrogen bond. 15 Graptophyllum pictum extract can inhibit the growth of Streptococcus mutans bacteria. ${ }^{16}$

Based on those backgrounds, arouse problem questions, whether Graptophyllum pictum influencing the plaque formation on acrylic resin complete denture or not. This is stated in the purpose of this study. Hopefully this study may give the information whether Graptophyllum pictum extract is suitable as a cleansing agent for acrylic resin complete denture.

\section{MATERIALS AND METHOD}

In this study, extract of Graptophyllum pictum was made by means of: 100 grams dried old leaves of Graptophyllum pictum, grounded to powder form, and then extracted in $70 \%$ ethanol with sohlet instrument for 2-3 hours until the process of extraction finished. The extract solution was concentrated with a Vacuum Rotary Evaporator to obtain a dry extract form. The Graptophyllum pictum extract tester solution was made of 5 grams main extract added with distillate aqua until $100 \mathrm{ml}$ volume was reached, and then shook until homogenously mixed, and a $5 \%$ tester solution was obtained. To obtain $10 \%, 20 \%$ and $40 \%$ tester solution, the procedure was the same, except the quantity of Graptophyllum pictum extract was increased respectively 10, 20 and 40 grams.

The plaque accumulations on the surface of acrylic resin complete dentures were observed by clinical research method. The subjects observed consisted of complete upper dentures (CUD) wore by patients at the Prosthodontic Clinic, Faculty of Dentistry, Gajah Mada University with the following criterion: minimally the CUD had to be worn for 1 month. The patient's age were about 40 years old or more, and did not suffer of any systemic diseases. In this case forty research subjects were examined.

The first treatment of the study was the plaque examination, which attached on the complete denture by rubbing disclosing agent. Each CUD was taken out from the patient's mouth and washed with running water until the saliva disappeared. The disclosing agent was rubbed to the CUD surface evenly by means of cotton buds which was soaked in before, and then washed under running water and subsequently scored by modified Quigley Hein index. The CUD should be cleansed from the disclosing agent solution, and the plaque was scored until reaching zero.

The 40 research subjects in the second treatment were divided into four groups, where each consisted of 10 study subjects. The complete dentures in the first group were soaked in 5\% Graptophyllum pictum extract solution, the second group soaked in $10 \%$ solution, the third soaked in $20 \%$ and the last group soaked in $40 \%$ solution. Each complete denture was soaked for 15 minutes. Then the complete denture was removed out of the extract solution, brushed with a toothbrush using the soaking liquid. The patient wore back the denture for 4 hours. After 4 hours, the CUD was taken out, and washed with water until the saliva disappeared. The disclosing agent was rubbed on its surface, then washed off with water and scored by modified Quigley Hein index.

The plaque accumulation on the CUD surfaces were divided into 8 location parts, namely: 4 location on the buccal surface of CUD as follows: $A=$ right posterior buccal surface; $\mathrm{B}=$ right anterior buccal surface; $\mathrm{C}=$ left anterior buccal surface and $\mathrm{D}=$ left posterior buccal surface. And the other 4 location parts were on the fitting surface of the CUD (fit-surface facing to the palatum mucosa) as follows: $\mathrm{E}=$ right posterior fitting surface; $\mathrm{F}=$ left posterior fitting surface; $\mathrm{G}=$ right anterior fitting surface, and $\mathrm{H}=\mathrm{left}$ anterior fitting surface.

The counting of the plaque was scored according to modified Quigley Hein index: 0 score = no plaque; 1 score $=$ light plaque, denoting that $1 \%-25 \%$ of the area was covered with plaque; 2 score $=$ moderate plaque, $26 \%-50 \%$ of the area was covered with plaque; 3 score $=$ heavy plaque: $51 \%-75 \%$ of the area was covered with plaque; 4 score $=$ very heavy plaque: $76 \%-100 \%$ of the area was covered with plaque.

The total plaque score at 8 scored areas $(\mathrm{A}-\mathrm{H})$

CUD plaque score $=\frac{\text { The total plaque score at } 8}{8}$

The obtained data was analyzed by One-way variant-analysis and t-test. 


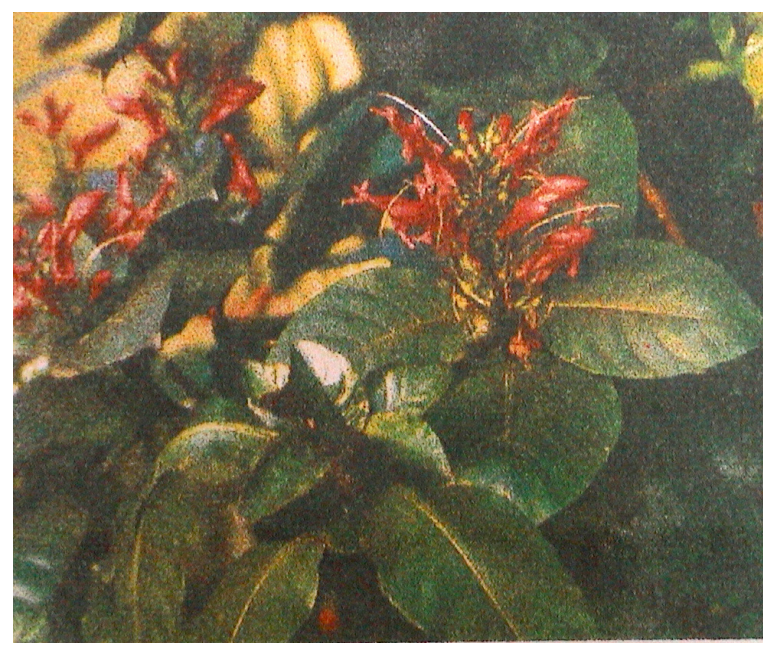

Figure 1. Graptophyllum pictum (daun ungu).plant

\section{RESULTS}

The average counting result of the plaque growth at the acrylic resin complete denture in each Graptophyllum pictum extract soaking group can be seen in table 1 .

Table 1. The average and standard deviation result of plaque formation after soaking in different Graptophyllum pictum extract concentration

\begin{tabular}{cccc}
\hline Concentration & $\mathrm{N}$ & Average & $\begin{array}{c}\text { Standard } \\
\text { deviation }\end{array}$ \\
\hline $5 \%$ & 10 & 2.729 & 0.002 \\
$10 \%$ & 10 & 1.925 & 0.008 \\
$20 \%$ & 10 & 1.166 & 0.007 \\
$40 \%$ & 10 & 0.425 & 0.005 \\
\hline
\end{tabular}

It was showed in Table 1 that the highest plaque growth was in 5\% Graptophyllum pictum extract, namely $2.729 \pm$ 0.002 , while the lowest plaque growth average was in $40 \%$ concentration, namely $0.425 \pm 0.005$.

To know the result differences between each study group, a One-way variant analysis was performed, which will show the significant difference of each Graptophyllum pictum extract concentration to the plaque growth on the acrylic resin complete denture $(\mathrm{p}<0.05)$.

A t-test was conducted to know the inter group differences, as seen in table 2 .

The t-test result in table 2 showed a significant difference among each different Graptophyllum pictum extract concentration soaking group, namely of 5\% and $10 \%$ concentration, $5 \%$ and $20 \%, 5 \%$ and $40 \%, 10 \%$ and $20 \%, 10 \%$ and $40 \%$, as well as $20 \%$ and $40 \%$ to the plaque growth existence on the acrylic resin complete denture $(\mathrm{p}<0.05)$.
Table 2. The t-test result of each inter group which CUD were soaked in different concentration of Graptophyllum pictum extract

\begin{tabular}{lcccc}
\hline Concentration & $5 \%$ & $10 \%$ & $20 \%$ & $40 \%$ \\
\hline $5 \%$ & - & $0.001 *$ & $0.001^{*}$ & $0.001^{*}$ \\
$10 \%$ & - & - & $0.001^{*}$ & $0.001^{*}$ \\
$20 \%$ & - & - & - & $0.001^{*}$ \\
$40 \%$ & - & - & - & - \\
\hline
\end{tabular}

\section{DISCUSSION}

The result of the study showed the highest plaque growth inhibition were found in those soaked in $40 \%$ Graptophyllum pictum extract solution, and the lowest inhibition were those soaked in 5\% concentration solution. The active composition content of Graptophyllum pictum were tannin and flavonoid. ${ }^{11}$ Tannin had the antibacterial power to inhibit glucose growth from Streptococcus mutans, so that it was able to get hold of the plaque growth. ${ }^{7}$ Based on those findings, presumably the low inhibiting effect result of the $5 \%$ Graptophyllum pictum extract solution, was caused by the low content of tannin and flavonoid, so that the solution was not effectively enough to inhibit. The $40 \%$ Graptophyllum pictum extract solution content higher tannin and flavonoid, so that it could function more effectively in the inhibition of the CUD's plaque growth. The outcome of this study was matched with Kozai et al finding, ${ }^{17}$ who explained that tannin could inhibit the formation of insoluble glucan from sucrose by glucotransferase which had an important role in the plaque growth.

The One-way ANOVA test result showed there was a significant difference in the Graptophyllum pictum extracts various concentrations to the plaque growth at acrylic resin complete denture $(\mathrm{p}<0.05)$. The $\mathrm{t}$-test result showed also a significant difference among acrylic resin complete dentures soaking in various Graptophyllum pictum extract solution groups to the existence of plaque growth $(\mathrm{p}<0.05)$. Result of the study showed that Graptophyllum pictum which content tannin and flavonoid has the ability to disrupt protein forming plaque. These study results was cause by tannin and flavonoid which was able to destroy protein, so that it can inhibit the plaque growth. The higher concentration of Graptophyllum pictum extracts solution, the more will be the amount of tannin and flavonoid, and consequently the inhibiting power will be higher to the plaque growth. These findings matching to Pelczar and Chan ${ }^{13}$ opinion that tannin could interact with protein and saliva pellicle to cause protein precipitation. Following $\mathrm{Wu}$ Yuan et al. ${ }^{7}$ tannin as a detoxification agent could precipitate protein and form a certain compound, that interact with protein and saliva pellicle to avoid attachment of Streptococcus mutans and lessen the bacteria's as well. 
The statement support the findings that Graptophyllum pictum extract could inhibit the growth of Streptococcus mutans. ${ }^{16}$ Harborne ${ }^{15}$ wrote that flavonoid was able to form a complex compound with protein by hydrogen bond, so that this protein precipitation could inhibit plaque growth.

Based on the study findings of Graptophyllum pictum extract solution on the plaque growth at the surface of CUD, a conclusion could be drawn as follows: the $40 \%$ concentration of Graptophyllum pictum extract had the highest plaque growth inhibition action on the denture. So Graptophyllum pictum extract solution can be suggested to be used as an alternative material for cleansing acrylic resin dentures.

\section{REFERENCES}

1. Phillips RW. Skinner's science of dental materials. $9^{\text {th }}$ ed. Philladelphia: WB Saunder Co; 1991. p. 199-204.

2. Combe EC. Notes on dental materials. $6^{\text {th }}$ ed. Edinburg: Churchill Livingstone. 1992; p. 79-120, 157-61.

3. Basker RM, Davenport JC, Tomlin, HR. Prosthodontics treatment for edontulous patient. $1{ }^{\text {st }}$ ed. London: The Macmillan Press; 1976. p. 163-5.

4. Roth GI, Calmes R. Oral biology. St Louis: The CV Mosby Co; 1981. p. 329-32, 369-71.
5. Jorgensen EB. Materials and methods for cleaning dentures. J Prosthet Dent 1979; 42(6):619-22.

6. Abelson DG. Denture plaque and denture cleanser. J Prosthet Dent 1981; 42:376-9.

7. Wu Yuan $\mathrm{CD}$, Chen $\mathrm{CY}, \mathrm{Wu}$ RT. Gallotanins inhibit growth, water insoluble glucan synthesis, and aggregation of mutans Sreptococcoci. J Dent Res 1988; 1:51-5.

8. Dills SS, Olshan AM, Goldner S, Brogdon S. Comparison of the antimicrobial capability of an abrasive paste and chemical soak denture cleanser. J Prosthet Dent 1988; 60:467-70.

9. Woodall JR. Comprehensive dental hygiene care. $2^{\text {nd }}$ ed. St Louis: CV Mosby Co; 1985. p. 204-9.

10. Setiawan D. Atlas tumbuhan obat Indonesia. Jilid 1. Yogyakarta: Trubus agriwidya; 1999. h.16-7.

11. Thomas ANS. Tanaman obat tradisional II. Yogyakarta: Kanisius; 1992. h. 9-10.

12. Martin EW, Cook EF. Remingtons practice on pharmacy. $12^{\text {th }}$ ed New York: Mack Publishing Co; 1961. p. 67-9.

13. Pelczar MJ, Chan ECS. 1988. Dasar-dasar mikrobiology. Hadioetomo RS, dkk. Jakarta: Penerbit Universitas Indonesia; 1988. h. $456-8$.

14. Jawetz EM. Review of medical microbiology. $16^{\text {th }}$ ed. San Francisco: Longo Medical Pub; 1986. p. 143-8, 297-9.

15. Harbone. Denture plaque distribution and the effectiveness of denture cleaner. Quintessence Int 1987; 27:341-5.

16. Wahyuningtyas E, Indrastuti M. Pengaruh ekstrak Graptophylum pictum terhadap pertumbuhan bakteri Streptococcus Mutans pada resin akrilik. Maj Ked Gigi (Dent J); Edisi Khusus Temu Ilmiah Nasional IV 2005:298-301.

17. Kozai K, Shoto M, Yamaguchi M, Nagasaka N, Pradopo S. Potential of gambir as an inhibitor of dental plaque formation. Maj Ked Gigi (Dent J)1995; 28:(5):95-6. 